\title{
外国文献
}

- Diagnosis, Staging, and Criteria of Response to Therapy for Lung Cancer:

- Date on Malignancy-Associated Changes in Oral and Bronchial Epithelial Cells in Sputum Specimens: Their Possible Utilization for Identification and Followup of High-Risk Groups:

- Reliability of Cytologic Diagnosis in Cancer of the Lung:

- A propos d'un cas d'epithélioma à cellules géantes du poumon diagnostiqué par examen cy tologique des expectorations:

- Bronchial Brushing Technique for the Cy tologic Diagnosis of Peripheral Lung Lesions:

- A Technical Aid in the Cytologic Diagnosis of Exfoliative Cells in Pulmonary Pathology:

- Preoperative Tomographic Assessment of the Mediastinum in Bronchial Carcinoma:

- Die Angiographie beim inoperablen Bronchuskarzinom:

- Die Bedeutung von verschiedenen Szintigraphie-Techniken in der Differentialdiagnose der Lungengeschwülste, Mit 13 Abblidungen:

- Ergebnisse der kombinierten ${ }^{133}$ Xe-/MAPLungenszintigraphie beim Bronchialkarzinom:

- Biopsy of Nonpalpable Scalene Lymph Nodes in Carcinoma of the Lung:

- Die Bedeutung bioptischer Verfahren bei der Diagnostik der Lungenkrankheiten:

- The Flexible Fiberscope in Bronchoscopic Perspective:

- Keynote Address on Diagnosis, Staging, and Criteria of Response to Therapy for Lung Cancer:

- The Incidence of Osseous Involvement in Lung Cancer, with Special Reference to the Development of Osteoblastic
D.T. Carr

F. Rilke, et al.

J.M. Lukeman

P. Plamenac, et al.

M. Bibbo, et al.

A.J. Schroit, et al.

P.K. Peace, et al.

F. Olbert

R. Pardon, et al.

H. Rösler, et al.

J.W. Brantigan, et al.

U. Müller, et al.

G.F. Tucker, Jr., et al.

D.T. Carr

L.D. Napoli
Cancer Chemother. Rep., $4: 2$ 303-306, '73.

Cancer Chemother. Rep., $4: 2$ 73-78, '73.

Cancer Chemother. Rep., $4: 2$

79-94, '73.

Poumon et Coeur, 29:1 83-86, '73.

J. clin. Cytol., 17:3 245-251, '73.

Acta Cytol., 17:2 118-120,'73.

Thorax, 28:3 367-370, '73.

Wien. Klin, Wschr., 85:16 Suppl. 9, '73.

Z. Erkrank. A., 137:3 362-369, '73.

Schweiz. med. Wschr., 103:29

1034-1042,'73.

Amer. Rev. Respirat. Dis., 107:6 962-974, '73.

Z. Erkrank. A., 137:3 370-374, '73.

Chest, 64:2 149,'73.

Cancer Chemother. Rep., 4:2

17-18,'73.

Radiology, 108:1 17-22, '73. 
Changes:

- Bronchial Carcinoma Metastases Presenting as Gluteal Abscess:

- Metastatic bronchogenic carcinoma to the maxilla:

- Lungentuberkulose-Risikofaktor für Lungenkrebs

- Lung Cancer in Chloromethyl Methyl Ether Workers:

- Cancer of respiratory organs among Workers at a nickel refinery in Norway:

- Relationship between Cigarette Smoking and Histological Type of Lung Cancer in Women:

- The Epidemiology of Different Histologic Types of Bronchogenic Carcinoma:

- Histogenesis of Squamous Metaplasia and Squamous Cell Carcinoma of the Respiratory Epithlium in an Animal Model:

- Cell-Mediated Immunity in Lung Cancer Patients: Data, Problems, and Propositions:

- Carcinoembryonic antigen in patients with carcinoma of the lung:

- Salivary Immunoglobulins in Patients with Oropharyngeal and Bronchopulmonary Carcinoma:

- Morphologic Classification of Bronchogenic Carcinoma:

- Clinical Staging of Primary Lung Cancer:

- Observer Variability and Reliability in Lung Cancer Diagnosis:

- Lung Cancer Detected by Semiannual Screening:

- Initial Therapeutic Trial of New Drugs in Lung Cancer:

- Chemotherapy of Lung Cancer: The Experience of the National Cancer Institute of Milan:

- Chemotherapy for Lung Cancer at the Institute of Experimental and Clinical Oncology, Academy of Medical Sciences, USSR:

- Kinetic Scheduling of Vincritine (NSC67574) and Bleomycin (NSC-125066) in Patients with Lung Cancer and Other Malignant Tumors:

- Comparison of Two Dose Schedules of Dichloromethotrexate (NSC-29630) in Lung Cancer:

\section{T. Ramanathan}

Adler, et al.

W. G. Figueroa, et al.

E. Pedersen, et al.

A. Kennedy

C.C. Harris

C.C. Harris, et al.

L. Israel

R.C. Vincent, et al.

M.A. Mandel, et al.

M.J. Matthews

G.A. Guinn, et al.

R. Yesner

K.R. Boucot, et al.

O.S. Selawry

G. Bonadonna, et al.

N.I. Perevodchikova, et al.

R.B. Livingston, et al.

P.R. Band, et al.
Brit. J. Dis. Chest, 67:April 167-168,'73.

J. oral Surg., 31:7 543-546, '73.

Med. Klin., 68:10 14, '73.

New Engl. J. Med., 288:21

1096-1097, '73.

Int. J. Cancer, 12:1 32-41, '73.

Thorax, 28:2 204-208,'73.

Cancer Chemotherapy Rep., 4:2 59-62, '73.

Cancer Chemother. Rep., 4:2 43-54, '73.

Cancer Chemother. Rep., 4:2 279-282, '73.

J. Thorac. cardiovasc. Surg., 66:2 $320-328$, '73.

Cancer, 31:6 1408-1413, '73.

Cancer Chemother. Rep., $4: 2$ 299-302, '73.

Chest, 64:1 51-54, '73.

Cancer Chemother. Rep., 4:2 55-58, '73.

J. Amer. med. Ass., 224:10 1361-1371, '73.

Cancer Chemother. Rep., 4:2 215-226, '73.

Cancer Chemother. Rep., 4:2 $231-238, ' 73$.

Cancer Chemother. Rep., 4:2 251-256, '73.

Cancer Chemother. Rep., 57:2 219-224, '73.

Cancer Chemother. Rep., 57:1 79-82, '73. 
- Status Report of Adjuvant Cancer Chemotherapy Trials in the Treatment of Bronchial Carcinoma:

- Monochemotherapy of Bronchogenic Carcinoma with Special Reference to Cell Type:

- Chemotherapeutic Studies in Bronchogenic Carcinoma by the Austrian Study Group:

- New Agents and Combinations in the Treatment of Bronchogenic Carcinoma:

- Preliminary Clinical Assessment of ICRF 159 (NSC-129943) in Bronchogenic Carcinoma-Abstract:

- Phase II Study of the Effect of MethylCCNU (NSC-95441) on Bronchogenic Carcinoma:

- Clinical Evaluation of an Innoxious Antineoplastic Agent: Preliminary Study of 106 Patients Treated with or without RSV After Pulmonary Resection for Bronchogenic Carcinoma:

- Bronchogenic Carcinoma: New Drugs Available for Study:

- Treatment of Bronchogenic Carcinoma with Surgery and Radiotherapy: The Experience of the National Cancer Institute of Milan:

o. Introduction to the 1st International Workshop for Therapy of Lung Cancer:

- Aspects of the Immunologic Treatment of Lung Cancer:

- Preliminary Results of Nonspecific Immunotherapy for Lung Cancer:

- Adjuvant Immunotherapy for Bronchogenic Carcinoma: Preliminary Results:

- Management of Oat Cell Carcinoma of Lung with Metastases:

- Zur lokalen Therapie maligner Pleuraergüsse:

- Some Thoughts on Surgical Adjuvant Studies in Lung Cancer:

- Comparative Results of Right Pneumonectomy and Sleeve Lobectomy:

- Keynote Address on Surgery in the Therapy for Lung Cancer:

Surgical Prospects and Priorities for Clinical Research:

- Radiotherapy for Bronchogenic Carcinoma: Actual Difficulties and Plans for the Future:
T.W. Shields

O.S. Selawry

K. Karrer, et al.

C.P. Bodey, et al.

K. Hellmann

H. Takita, et al.

J.L. Hansen

M. Slavik, et al.

P. Sucalossi, et al.

O.S. Selawry

G. Alth, et al.

L. Israel

H. Takita, et al.

J.L. Cohen, et al.

R. Titscher, et al.

S.K. Carter

A.-P. Naef, et al.

C.F. Mountain

M. Dana
Cancer Chemother. Rep., 4:2 119-124, '73.

Cancer Chemother. Rep., 4:2 177-188, '73.

Cancer Chemother. Rep., 4:2 207-214, '73.

Cancer Chemother. Rep., 4:2 227-230, '73.

Cancer Chemother. Rep., 4:2 243-244, '73.

Cancer Chemother. Rep., $4: 2$ 257-260, '73.

Cancer Chemother. Rep., 4:2 261-264, '73.

Cancer Chemother. Rep., 4:2 265-270, '73.

Cancer Chemother. Rep., 4:2 $101-108, ' 73$.

Cancer Chemother. Rep., 4:2 5-6, '73.

Cancer Chemother. Rep., 4:2 271-274, '73.

Cancer Chemother. Rep., 4:2 283-286, '73.

Cancer Chemother. Rep., $4: 2$ 293-298, '73.

J. Amer. med. Ass., 225:4

422, '73.

Wien. Klin. Wschr., 85:18

338-340, '73.

Cancer Chemother. Rep., 4:2 109-118, '73.

Cancer Chemother. Rep., 4:2 97-100, '73.

Cancer Chemother. Rep., 4:2 19-24, '73.

Cancer Chemother. Rep., 4:2 153-156, '73. 
- Radiation Therapy Techniques Suitable for Intercenter Cooperative Studies of Bronchogenic Carcinoma:

- Radiotherapy in Chest Malignant Tumors Associated with Pulmonary Tuberculosis:

- Radiation Therapy for Cancer of the Lung: Previous Experience and Definition of Current Issues:

- Radiotherapy for Lung Cancer:

- Keynote Address on Chemotherapy for Lung Cancer:

- Hyperamylasemia with Carcinoma of the Lung:

- A Case of Secondary Echinococcosis Diagnosed by Cytologic Examination of Pleural Fluid and Needle Biopsy of Pleura:

O Metaplastic Bone Formation in the Lung:

- The Principles of Predicting the Risk of Post-Thoracotomy Function-Related Complications in Bronchial Carcinoma:

- Bewertung der Lungenpunktion zur Zytologischen Diagnose des Bronchialkarzinoms:

O Small cell carcinoma of the lung: Clinicopathological studies:

- Lung Carcinoma Associated with Production of Three Placental Proteins:

- Frequency of Residual and Metastatic Tumor in Patients Undergoing Curative Surgical Resection for Lung Cancer:

- The Surgeon's Viewpoint on Collaborative Research on Lung Cancer:

- The Spectrum of Diffuse Pulmonary Infiltration in Malignant Disease:

- The Growth Rate of Bronchogenic Carcinoma: Is It Constant?

- Intrathoracic Lesions Mimicking Cancer:

- Compaign against lung cancer in the U.S.:

- Correlation of Histologic Types with Cell Kinetic Studies in Lung Cancer:

- Keynote Address on Pathology of Lung Cancer:

- Human Peripheral Lung Tumours: Light and Electron Microscopie Correlation:

- Ultrastructure of Bronchial Oncocy toma:
R. Sealy, et al.

L.L. Fulkerson, et al.

C.A. Perez

P. Rubin

H.H. Hansen

R.W. Ammann, et al.

E.S. Jacobson, et al.

A.N. Jacobs, et al.

P. Lockwood

J. Engel, et al.

H. Takita, et al.

M.A. Charles, et al.

M.J. Matthews, et al.

C.F. Mountain

M.I. Schwarz, et al.

W. Weiss

E.A. Sickles, et al.

F.M. Muggia

M.J. Mathews

Mollo, et al.

R.E. Fechner, et al.
Cancer Chemother. Rep., 4:2 137-144, '73.

Radiology, 106:3 645-648, '73.

Cancer Chemother. Rep., 4:2 145-152,'73.

Cancer Chemother. Rep., 4:2 311-316,' 73 .

Cancer Chemother. Rep., 4:2 25-28, '73.

Ann. intern. Med., 78:4 521-526, '73.

Acta cytol., 17:1 76-79, '73.

Amer. J. Roentgenol., 118:2

344-346, '73.

Respiration, 30:4 329-344, '73.

Praxis der Pneumol., 27:8

491-494, '73.

J. thorac. cardiovasc. Surg., $66: 3$ 472-477,'73.

Arch. int. Med., 132:3 427-431, '73.

Cancer Chemother. Rep., 4:2

63-68, '73.

Cancer Chemother. Rep., 4:2

307-310, '73.

Chest, 64:1 88-93, '73.

Cancer, 32:1 167-171, '73.

J. Amer. med. Ass., 225:2

156-157, '73.

Nouv. Presse Méd., 2:13 855, '73.

Cancer Chemother. Rep., 4:2

69-72,'73.

Cancer Chemother. Rep., 4:2

15-16,'73.

Brit. J. Cancer, 27:2 173-182, '73.

Cancer, 31:6 1451-1457, '73. 